SCHOLARS: Journal of Arts \& Humanities

Volume 2, August 2020, pp. 1-13

[Peer-Reviewed, Open Access, Indexed in NepJOL]

Print ISSN: 2773-7829; e-ISSN: 2773-7837

DOI: https://doi.org/10.3126/sjah.v2i0.35008

Central Department of English

Tribhuvan University

Kirtipur, Kathmandu, Nepal

www.cdetu.edu.np/ejournal/

Original Research Article

\title{
Quality Assurance in Higher Education Institutions: The Case of Tribhuvan University
}

\author{
Min Pun, PhD \\ Department of English \\ Prithvi Narayan Campus, TU, Pokhara, Nepal
}

\begin{abstract}
The main objective of this paper is to illustrate the current status of quality assurance practices and identify challenges and opportunities facing Tribhuvan University (TU) in general and higher education institutions of $T U$ in particular. Apart from a range of benefits and prospects from adopting and implementing the Quality Assurance and Accreditation (QAA) system within TU, it has been facing a number of challenges in maintaining quality in its higher education institutions. In return, the implementation of the system can create a number of opportunities, particularly it has to internationalize its higher education and show a strong presence in the world university rankings. In order to meet this objective, the study has used a descriptive-analytical approach to find out the issues related to quality assurance in higher education institutions. Finally, the paper has made important policy implications and recommendations to support the ongoing efforts of UGC, Nepal and maintain and ensure quality in higher education institutions of $T U$.
\end{abstract}

Keywords: Accreditation, higher education, quality assurance, world university rankings

\section{Introduction: Where Does TU Stand Now?}

Over the last three decades, the issue of quality assurance in higher education institutions has been one of the top concerns for almost all universities around the world as the quality assurance system has become a global trend that has compelled them to rethink about their status quo. The universities should increase the standards of their education that are "abreast with global university expectations" (Muchemwa 93). One of the reasons for this is largely due to the fact that the impact of quality higher education can contribute to the overall progress of the country (El-Khawas 10). Such progress includes economic growth, production of human resources, and internationalization of higher education.

In the new era of globalization today, higher education is also increasingly considered more globalized and competitive among the universities worldwide. So today's higher education is considered as global education (Altun 82). This increasing global trend has made the stakeholders such as academics, administrators, and governments more aware of quality assurance in higher education in order to improve 


\section{Quality Assurance in Higher Education Institutions 2}

their status among the universities in the world (Portnoi and Bagley). This global trend of quality assurance in higher education is being further escalated by the world university ranking systems, “changing the universities' landscape” (Sherwani 7). The QS World University Rankings, the World University Rankings by The Times Higher Education, and the Webometrics July 2020 by the Ranking Web of Universities are some examples of the system of ranking universities that have become attraction for many universities worldwide. As for Portnoi and Bagley, this system has fueled competition, which is considered as central to evaluate the excellence of universities in the world. In Nepal's case, as shown in Table 1, the Tribhuvan University (TU), established in 1959, is the single most important university to represent a nation in the reputed world university rankings.

Table 1

Status of Nepal's universities among universities around the world - 2020 \& 2021

\begin{tabular}{lccc}
\hline \multicolumn{1}{c}{ University } & $\begin{array}{c}\text { World University } \\
\text { Rankings 2021 (The } \\
\text { Times Higher } \\
\text { Education) }\end{array}$ & $\begin{array}{c}\text { Asia University Rankings } \\
\text { (The Times Higher } \\
\text { Education) }\end{array}$ & $\begin{array}{c}\text { Webometrics July } \\
\text { 2020 (Ranking Web } \\
\text { of Universities) }\end{array}$ \\
\cline { 2 - 4 } & $\begin{array}{c}\text { Out of Top 1,500 } \\
\text { Universities from 93 } \\
\text { Countries }\end{array}$ & $\begin{array}{c}\text { Out of Top 500 } \\
\text { Universities from 30 } \\
\text { Asian Countries }\end{array}$ & $\begin{array}{c}\text { Out of 30,000 } \\
\text { Universities }\end{array}$ \\
\hline Tribhuvan University & $801-1000$ & $351-400$ & 3804 \\
Kathmandu University & 0 & 0 & 3169 \\
BP Koirala Institute of & 0 & 0 & 4932 \\
Health Sciences & 0 & 0 & 5651 \\
Pokhara University & 0 & 0 & 14400 \\
Purbanchal University & 0 & 0 & 15727 \\
Agriculture \& Forestry & 0 & 0 & 19367 \\
University & 0 & 0 & 20759 \\
Mid-Western University & 0 & 0 & 26312 \\
Lumbini Buddha University & 0 & 0 & \\
Far-Western University & 0 & 0 & \\
\hline
\end{tabular}

Source: Asia University Rankings 2020. The Times Higher Education, 18 July 2020, www.timeshighereducation.com/world-university-rankings/2020/; World University Rankings 2021. The Times Higher Education, 31 August 2020, www.timeshighereducation.com/ world-university-rankings/2021/world-ranking\#!/ page/0/ length/25/name/ tribhuvan\%20 university/sort_byrank/sort_order/asc/cols/stats; Webometrics July 2020. Ranking Web of Universities, 12 August 2020, www.webometrics.info/en.

Table 1 demonstrates that TU has entered the top world university rankings as compared to other universities in Nepal despite that fact that TU bears the burden of almost $80 \%$ of the total higher education students' enrolment in the country (University Grants Commission 47). According to The Times Higher Education based in the United Kingdom has published its results for the year 2021 recently, TU is ranked 351-400 among top 500 Asian universities that covered 33 Asian countries. It was ranked 8011000 among top 1,500 world universities representing 93 countries. The results of the Webometrics July 2020 published for the year 2020 by the Ranking Web of Universities shows that TU has also stood in the $3,804^{\text {th }}$ position among 30,000 universities worldwide. Only a few other universities in Nepal have entered the reputed world 
university rankings through the Ranking Web of Universities. They include Kathmandu University ranking highest with $3,169^{\text {th }}$ position and Far-Western University ranking lowest with $26,312^{\text {nd }}$ position among the universities in Nepal. The data displayed in Table 1 show that many universities in Nepal are currently not viable participants in this global reputation competition. So, in a world of increasingly global competition, TU has an important academic leadership role in national and international higher education as there is growing impact of world rankings on higher education.

Together, the world university rankings system and the higher education quality assurance system go hand in hand. For instance, the world university rankings system evaluates and ranks the best universities in the world based on quality assurance indicators of higher education institutions. In line with its plan to show its higher education standards and a strong presence in the global quality competition, the University Grants Commission (UGC), Nepal has established the Quality Assurance and Accreditation Council (QAAC) as a statutory body in 2007 that advises on quality in higher education institutions and recognizes "the quality of the programs and HEIs on the basis of reviews, assessments and audits of the programs and the HEIs" (Quality Assurance and Accreditation Division, Quality Assurance 2). In line with the same plan, TU established the Centre for Quality Assurance (TUQA Centre) in 2018 to monitor and facilitate its constituent campuses, faculty/institutes, and central departments participating in the Quality Assurance and Accreditation (QAA) process (TUQA Centre).

Therefore, this paper aims to map the status quo of quality assurance practices within TU and its higher education institutions (including campuses, faculty/institutes, and central departments) by describing policies and their impacts on improving the quality of higher education and reputation it has achieved in the world university rankings. The paper has also focused on the identification of challenges that higher education institutions of TU is facing while assuring quality of education and opportunities that the quality assurance practices have created for the future. Finally, the paper has made recommendations for future quality aspects to improve sustainable quality assurance culture within the university and to maintain a strong presence in the world university rankings.

\section{Methodology}

The study has been conducted by using a descriptive-analytical method to explore the issues related to quality assurance in higher education institutions of TU. Both primary and secondary data have been used for the study. For instance, it has used the analysis of documents retrieved from secondary sources and interviews with key informants, and observation of the site as primary sources of data. TU was selected to allow an in-depth study of the current status of quality assurance policies and practices, challenges and opportunities facing the university for the last two decades or so. It was selected as the study area because TU is within the reach of this author and has been an active participant in developing and implementing quality assurance system in one of higher education institutions of the university.

The data were collected over a period of six months by means of a study of both primary and secondary sources, information retrieved from the key informants and direct observation. Documents used in this study were collected from policy papers, reports, and other publications of the Government of Nepal and QAAC of UGC, Nepal. 


\section{Quality Assurance in Higher Education Institutions 4}

Similarly, documents were also collected from both print and online sources such as journal articles, books, book chapters, and seminar/conference/workshop papers on quality assurance in higher education and related issues. The key informants included the officials of TU and UGC, Nepal, including the campus chiefs and the Internal Quality Assurance Committee (IQAC) members of different constituent, community, and private higher education institutions of TU. They were selected because quality assurance in higher education institutions is depended upon the role of quality managers (Seyfried and Pohlenz 258). They were interviewed in-depth in order to extract relevant data to the issues. 10 participating higher education institutions which were in the QAA process, both accredited and in the process of getting accredited, were visited by the researcher. The field visits were conducted mainly to observe the sites and acquire information about their status quo.

In this way, both quantitative and qualitative data were extracted, reviewed, and analyzed before they were included in this paper. They were mainly used for analysis that dealt with the issues of quality assurance in higher education institutions of TU.

\section{Results and Discussion}

With the establishment of UGC, Nepal in 1993, higher education in Nepal enters the global trend of assuring quality in higher education as it requires UGC to be responsible for "carrying out functions to motivate for providing quality education having determined academic standards of universities” (The University Grants Commission Act 1). In order to meet this mandate, UGC has been continuously working towards developing the national QAA system to ensure quality in higher education institutions through its QAAC, which is a step towards the international practice of accreditation system in higher education institutions in Nepal.

Currently, in Nepal, 11 universities and four university-equivalent higher education institutions are in operation. TU is the largest university in Nepal in terms of the number of students, teachers, and campuses. As shown in Table 2, out of 1,425 higher education institutions, TU holds 1,140 campuses across the country; out of 9,269 university teachers, it holds 7,592; and out of the total of 423,996 students in the country, it holds 335,126 students.

Table 2

Status of higher education institutions in Nepal 2017/18

\begin{tabular}{clccc}
\hline SN & \multicolumn{1}{c}{ Name of University/HEI } & Campuses & Teachers & Students \\
\hline 1 & Tribhuvan University & 1140 & 7592 & 335126 \\
2 & Nepal Sanskrit University & 18 & 484 & 3742 \\
3 & Kathmandu University & 23 & 388 & 17942 \\
4 & Pokhara University & 62 & 133 & 29419 \\
5 & Purbanchal University & 131 & 74 & 26128 \\
6 & Lumbini Buddha University & 6 & 23 & 705 \\
7 & Agriculture \& Forestry University & 8 & 122 & 1978 \\
8 & Mid-Western University & 16 & 128 & 3224 \\
9 & Far-Western University & 15 & 109 & 3686 \\
10 & Nepal Open University & 0 & N/A & 593 \\
\hline
\end{tabular}

SCHOLARS: Journal of Arts \& Humanities

Volume 2, August 2020 
Quality Assurance in Higher Education Institutions 5

\begin{tabular}{llccc}
\hline 11 & Rajarshi Janak University & 1 & N/A & 81 \\
12 & National Academy of Medical & & N/A & 441 \\
& Sciences & 1 & 216 & 540 \\
13 & Patan Academy of Health Sciences & 1 & N/A & 361 \\
14 & BP Koirala Institute of Health & 1 & N/A & 30 \\
\cline { 2 - 3 } 15 & Sciences & 1 & 9,269 & 423,996 \\
\hline Total & Karnali Academy of Health Sciences & 1,425 & & \\
\hline
\end{tabular}

Source: University Grants Commission. Education Management Information System:

Report on Higher Education 2017/18. University Grants Commission, 2019.

The data displayed in Table 2 demonstrate that, though many universities are operating various academic programmes, TU holds the largest percentage of the total number of higher education students. According to Upadhyay, TU bears "the sole responsibility of providing higher education in the country" (97), meaning that the country cannot progress if TU does not produce quality human resources. For this purpose, it is necessary for TU to maintain and assure quality in higher education that it provides.

With the beginning of quality assurance system in Nepal, TU has continuously participated in the higher education reform initiatives as taken by UGC, Nepal. One of the higher education reform initiatives is the QAA system of UGC, Nepal through its QAAC. Regarding the role of quality assurance system, Saeed has argued that quality assurance plays an important role in improving the academic performance of the universities (178). Here, Figure 1 reveals the status of QAA activities as participated by higher education institutions in Nepal, which is the overall status of participating institutions representing all universities and their constituent and affiliated campuses.

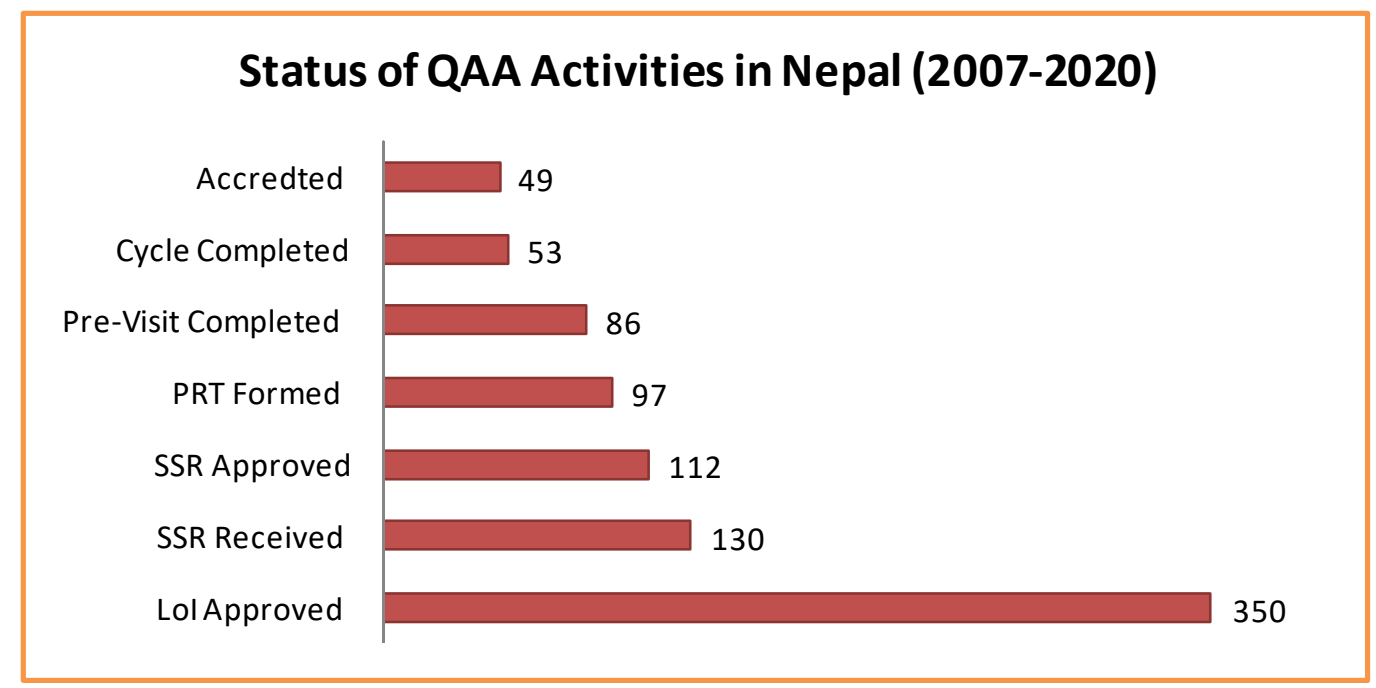

Fig. 1. Chaulagai, Nabina. "Status of QAA activities of higher education institutions in Nepal by university from 2007 to 2020.” Received by Min Pun, 28 June 2020. Email Interview.

Note: These terminologies are used by UGC, Nepal. Accordingly, the full form of LoI is Letter of Intent; SSR is Self-Study Report; PRT is Peer Review Team.

As demonstrated in Figure 1 that covers higher education institutions of all universities in Nepal, 350 higher education institutions (including constituent, 
community and private campuses, faculty/institutes/schools, and central departments) have received the Letter of Intent (LoI), showing their interest to participate in the QAA process. QAAC has approved 112 out of 130 Self-Study Reports (SSR), formed 97 Peer Review Teams (PRT), and completed 86 pre-visits to evaluate the participating institutions. Similarly, 49 participating institutions have received accreditation from UGC, Nepal and 53 institutions have completed the QAA cycle. The data shown in Figure 1 and 2 indicate that very few higher education institutions have participated in the QAA process. For instance, only 350 institutions participating in the QAA process and 49 getting accredited out of 1,425 institutions from 11 universities and four university-equivalent institutions is non-existent, but the participation trend is gradually growing day by day.

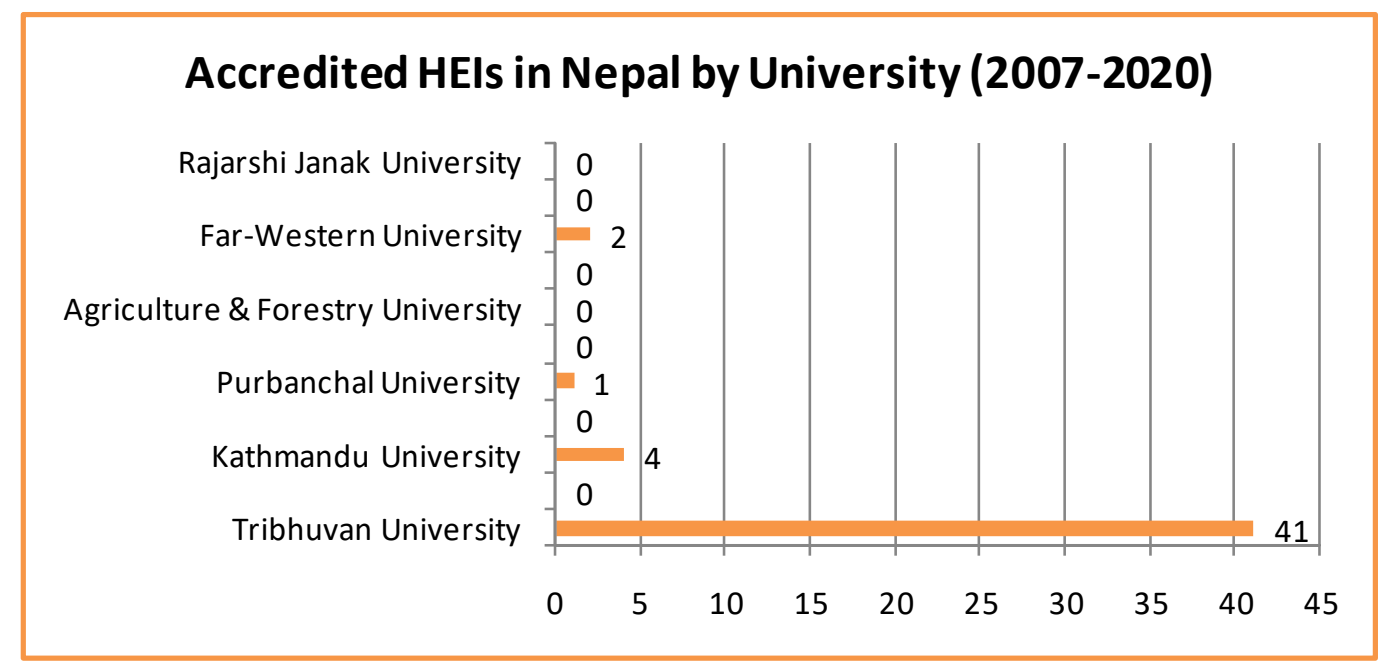

Fig. 2. Chaulagai, Nabina. "Accredited higher education institutions by university 20072020.” Received Min Pun, 28 June 2020. Email Interview.

Note: The total number of accredited higher education institutions is 49 .

Interestingly, Figure 2 shows a strong presence of TU in the national QAA system, showing its 41 constituent, community and private campuses, and central departments getting accredited by UGC, Nepal. It is believed that quality in higher education can be attained through the accreditation process (Cura and Ahmed Alani 72). Despite the fact that the accreditation system brings quality in higher education, there are still many universities such as Nepal Sanskrit University, Pokhara University, Lumbini Buddha University, Agriculture \& Forestry University, Mid-Western University, Nepal Open University, and Rajarshi Janak University, which have not yet entered the QAA system. Apart from these universities, there are university-equivalent higher education institutions which are not included in this figure that are also not under this system as they are under various professional councils in relation to quality assurance and control system that include some of technical and professional academic programmes of universities of Nepal including TU.

Now, if we look into the QAA activities of TU higher education institutions, TU has a strong presence in UGC's efforts to maintain quality in higher education in Nepal as compared to institutions of other universities. In fact, UGC and TU have worked together in their efforts to reform higher education in Nepal. For instance, Figure 3 shows the data of accredited TU campuses and central departments from 2007 to 2020. 


\section{Accredited TU HEls by Institution-Type (2007-2020) (Total $=\mathbf{4 1})$}

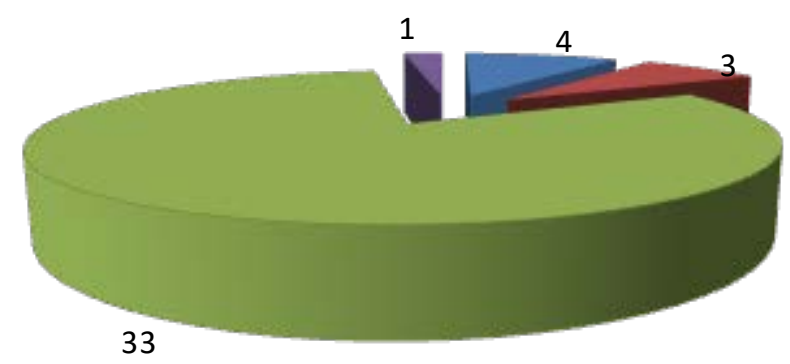

$\square$ Constituent (4) $\quad \square$ Department (3) $\square$ Community (33) $\quad$ Private (1)

Fig. 3. Chaulagai, Nabina. "Status of Accredited TU Higher Education Institutions by Institution-Type from 2007 to 2020.” Received by Min Pun, 28 June 2020. Email Interview.

As stated above, in Figure 3, TU holds a strong presence in the QAA activities of UGC, Nepal because out of the total of 49 accredited higher education institutions in Nepal, 41 such institutions belong to TU. To date, four constituent campuses, three central departments, 33 community campuses and one private campus are accredited institutions of TU.

Following the notice of UGC, Nepal for all higher education institutions operating in Nepal to come under the QAA system within the next five years (Notice), higher education institutions of TU have responded positively towards this directive. Figure 4 shows the comparative study of the participation of TU campuses and central departments in the accreditation process of UGC, Nepal.

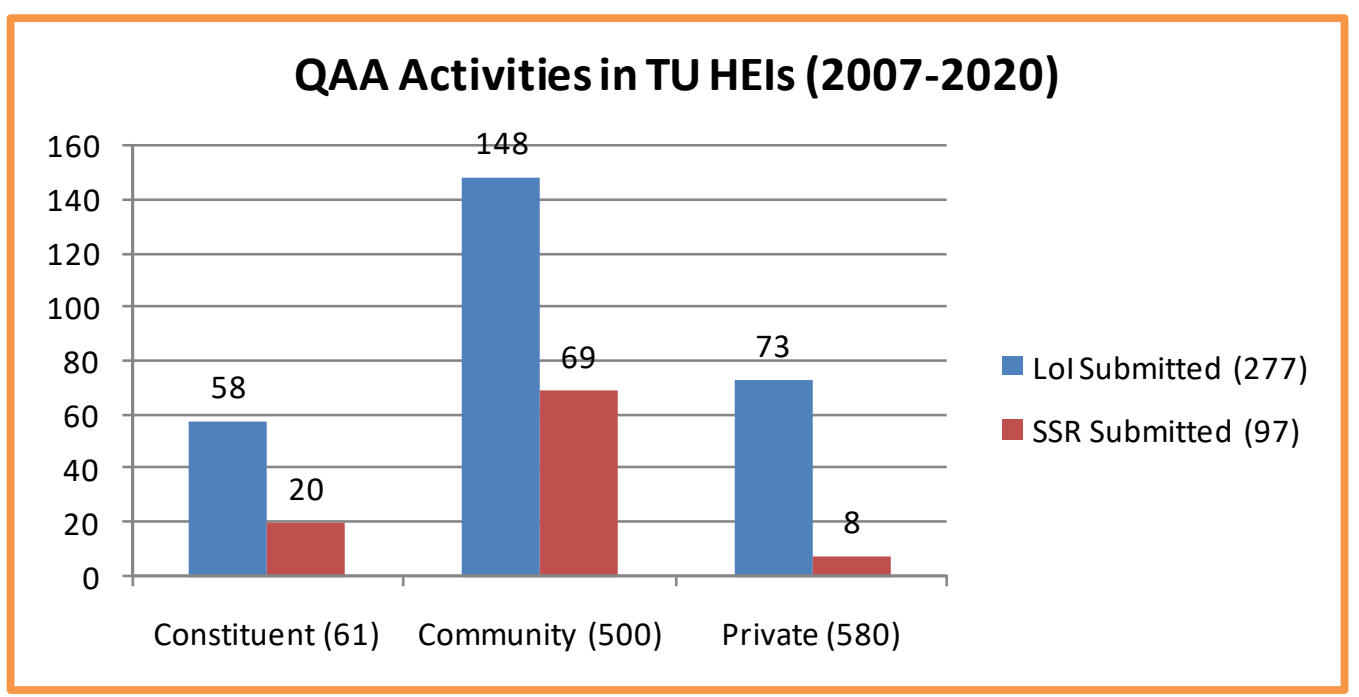

Fig. 4. Acharya, Gopal. "Status of QAA activities of TU higher education institutions from 2007 to 2020.” Received byMin Pun, 8 June 2020. Email Interview.

As data presented in Figure 4 show, the participation of TU higher education institutions is still non-existent as compared to the number of campuses and central 
departments that TU has. For instance, out of 61 constituent campuses of TU, only 58 have submitted the LoI and 20 have submitted their SSR. Among 500 community campuses of TU across the country, only 148 community campuses have submitted their LoI and 69 have submitted their SSR. Similarly, among 580 private campuses of TU across the country, only 73 and eight such campuses have submitted their LoI and SSR respectively. Among three types of TU higher education institutions, according to the data shown here, private higher education institutions have not shown their interest in the QAA system due to the grant support that has been "the main attraction in the QAA system to motivate many campuses toward the QAA system” (Quality Assurance and Accreditation Division, Higher Education 14). Since the QAA system is mandated through the Second Higher Education Project (SHEP) as funded by the World Bank that does not support the private institutions. So private campuses whether they are affiliated to TU or other universities in Nepal do not receive this grant support from UGC. Overall, as Hillman and Baydoun suggest, it is essential that all universities and governments across the globe need to provide an encouraging environment to maintain and ensure quality in higher education institutions (13-14). So do the universities of Nepal.

\section{Conclusion and Recommendations}

The need of quality assurance in higher education institutions is currently experienced by all universities around the world. As higher education has become increasingly competitive, universities and governments have to rethink about their higher education status quo so that they could improve their position on the global higher education context. With the recent advent of world university ranking system, they have also become more aware of quality assurance system in higher education institutions across the world. Nepal is not an exception to this trend.

Realizing the fact that quality assurance in higher education is a global trend, the Government of Nepal established UGC in 1993 and UGC established QAAC in 2007 to maintain, monitor and ensure quality in higher education institutions in Nepal. As discussed above, TU has closely worked with UGC's efforts to improve quality in higher education. For instance, out of the total 49 accredited higher education institutions in Nepal, 41 such institutions belong to TU. Similarly, out of the total 350 participating institutions in the QAA process, 277 such institutions are part of TU. So as compared to other universities and their higher education institutions, TU has a strong presence in the QAA system of the country.

In addition, TU has also entered the world university ranking system as no other universities in Nepal have done so. For instance, according to World University Rankings conducted by The Times Higher Education for the year 2020 and 2021, only TU represents a nation to be ranked 351-400 among top 500 Asian universities and 8011000 among top 1,500 world universities respectively. Similarly, the Webometrics July 2020 by the Ranking Web of Universities, TU was ranked 3,804 among 30,000 world universities. Thus, TU's entry into the world university ranking systems is clear evidence that it is struggling hard to maintain quality in higher education in Nepal.

Despite the fact that its status as the largest university in Nepal, its active participation in the QAA system of the country, and the single most participation in the world university ranking systems, TU is facing many challenges while assuring quality in higher education that the QAA system has created for the future. Challenges include 
assuring quality in a large number of its constituent and affiliated campuses across the country, lack of funding to implement the quality assurance system, reluctant attitude of university and campus managers to participate in the QAA system, highly centralized university system that regulates its purpose, powers, and governance, and lack of qualified human resources to implement the quality assurance system. At the same time, if these challenges are addressed by TU in a timely manner, it can enjoy opportunities that the quality assurance practices can create for the future. Opportunities include its contribution to the overall progress of the country, entry into the global university ranking system, recognition of its institutions in and out of the country, and internationalization of higher education in the context of globalization.

Based on the results discussed above, this paper provides some policy implications and recommendations to support the ongoing efforts of UGC, Nepal to assure quality in TU in general and TU higher education institutions in particular. They are as follows:

- The accrediting national body like QAAC should be autonomous and free from the government influence and the political influence. QAAC should be kept separate from UGC, Nepal and made a powerful authority to monitor and assure quality in all types of higher education institutions.

- Funding for the QAA system is a key for sustainable development of the quality assurance system in higher education. If the existing SHEP does not continue to provide grant support for the QAA activities, TU should think about funding the activities. It is necessary to maintain quality in higher education because it will contribute to the national development.

- All higher education institutions whether they are constituent campuses or central departments, community campuses or private campuses operating under TU regulations should mandatorily enter into the QAA system in order to guarantee the quality in TU higher education institutions.

- The role of TUQA Centre should be strengthened in order to facilitate higher education institutions operating under TU regulations to participate compulsorily in the QAA system. Additionally, TUQA should work to meet the requirements and standards of the national quality assurance framework as well as facilitate the adoption and implementation of internal quality enhancement within TU higher education institutions.

\section{Works Cited}

Acharya, Gopal. "Status of QAA activities of TU higher education institutions from 2007 to 2020.” Received byMin Pun, 8 June 2020. Email Interview.

Altun, Mustafa. "What Global Education should Focus on." International Journal of Social Sciences \& Educational Studies, vol. 4, no. 1, 2017, pp. 82-86. Tishk International University, doi: 10.23918/ijsses.v4i1p93.

Asia University Rankings 2020. The Times Higher Education, 18 July 2020, www.timeshighereducation.com/world-university-rankings/2020/.

Chaulagai, Nabina. “Accredited higher education institutions by university 2007-2020.” Received Min Pun, 28 June 2020. Email Interview. 
---. "Current status of Accredited Higher Education Institutions in Nepal (2007- 2020).” Received by Min Pun, 28 June 2020. Email Interview.

---. "Status of Accredited TU Higher Education Institutions by Institution-Type from 2007 to 2020.” Received by Min Pun, 28 June 2020. Email Interview.

---. "Status of QAA activities of higher education institutions in Nepal by university from 2007 to 2020.” Received by Min Pun, 28 June 2020. Email Interview.

Cura, Fatih and Ahmed Alani, Teba. "Accreditation Effect on Quality of Education at Business Schools.” International Journal of Social Sciences \& Educational Studies, vol. 4, no. 5, 2018, pp. 71-82. Tishk International University, doi: 10.23918/ijsses.v4i5p71.

El-Khawas, Elaine. Quality Assurance in Higher Education: Recent Progress, Challenges Ahead. The World Bank, 1998.

Hillman, John. R. and Baydoun, Elias. "Quality Assurance and Relevance in Academia: A Review.” Major Challenges Facing Higher Education in the Arab World: Quality Assurance and Relevance, edited by Adnan Badran, Elias Baydoun and John. R. Hillman. Springer, 2019, pp. 13-68. Springer, doi: 10.1007/978-3-03003774-1_2. Accessed 13 July 2020.

Muchemwa, Stella. "University Quality Assurance in Zimbabwe: A Case of Solusi University.” International Journal of Social Sciences \& Educational Studies, vol. 4, no. 1, 2017, pp. 93-108. Tishk International University, doi: 10.23918/ijsses.v4i1p93.

Notice. University Grants Commission, 24 November 2017, http://ugcnepal.edu.np/\#ajaxpaginateNotices. Accessed 15 July 2020.

Portnoi, Laura M. and Bagley, Sylvia S. “Competitive Higher Education Landscape.” Trends \& insights. Royal Universities, 19 September 2018, https://www.royaluniversities.org/2018/09/competitive-higher-educationlandscape/. Accessed 15 July 2020.

Quality Assurance and Accreditation Division. Quality Assurance and Accreditation for Higher Education in Nepal: A Brief Guideline. University Grants Commission, 2013.

Quality Assurance and Accreditation Division. Higher Education Quality Assurance and Accreditation Council: Annual Report 2017/18. University Grants Commission, 2019.

Saeed, Sameerah T. "Impact of Quality Assurance on Academic Performance.” International Journal of Social Sciences \& Educational Studies, vol. 5, no. 1, 2018, pp. 178-190. Tishk International University, doi: 10.23918/ijsses.v5i1p178.

Seyfried, Markus and Pohlenz, Philipp. "Assessing Quality Assurance in Higher Education: Quality Managers’ Perceptions of Effectiveness.” European Journal of Higher Education, vol. 8, no. 3, 2018, pp. 258-271. Taylor \& Francis Online, doi: 10.1080/21568235.2018.1474777.

Sherwani, Karwan Hushyar. "Comparative Analysis of National University Ranking System in Kurdistan-Region and other National University Rankings: An Emphasis on Criteria and Methodologies.” International Journal of Social Sciences \& Educational Studies, vol. 5, no. 1, 2018, pp. 7-15. Tishk International University, doi: 10.23918/ijsses.v5i1p7. 


\section{Quality Assurance in Higher Education Institutions 11}

The University Grants Commission Act, 1993. Nepal Law Commission, www.lawcommission.gov.np/en/wp-content/uploads/2018/10/university-grantcommission-act-2050-1993.pdf.

TUQA Centre. Tribhuvan University Operational Guidelines for Quality Assurance. Tribhuvan University, 2018.

University Grants Commission. Education Management Information System: Report on Higher Education 2017/18. University Grants Commission, 2019.

Upadhyay, Jitendra Prasad. “Higher education in Nepal.” Pravaha Journal, 2018, pp. 96108. Nepal Journals Online, doi: 10.3126/pravaha.v24i1.20220.

Webometrics July 2020. Ranking Web of Universities, 12 August 2020, www.webometrics.info/en.

World University Rankings 2021. The Times Higher Education, 31 August 2020, www.timeshighereducation.com/ world-university-rankings/2021/worldranking\#!/page/0/ length/25/name/ tribhuvan\%20 university/sort_byrank/sort_order/asc/cols/stats.

\section{ANNEX:}

Current Status of Accredited Higher Education Institutions in Nepal (2007- 2020)

\begin{tabular}{|c|c|c|c|c|}
\hline S.N. & Name of the Institution & University & Type & Status \\
\hline 1 & $\begin{array}{l}\text { Mahendra Ratna Multiple Campus, } \\
\text { Ilam }\end{array}$ & $\begin{array}{l}\text { Tribhuvan } \\
\text { University }\end{array}$ & Constituent & Accredited \\
\hline 2 & Prithvi Narayan Campus, Pokhara & $\begin{array}{l}\text { Tribhuvan } \\
\text { University }\end{array}$ & Constituent & Accredited \\
\hline 3 & Pulchowk Campus & $\begin{array}{l}\text { Tribhuvan } \\
\text { University }\end{array}$ & Constituent & Accredited \\
\hline 4 & Mechi Multiple Campus & $\begin{array}{l}\text { Tribhuvan } \\
\text { University }\end{array}$ & Constituent & Accredited \\
\hline 5 & $\begin{array}{l}\text { Central Department of Environmental } \\
\text { Science, Kirtipur }\end{array}$ & $\begin{array}{l}\text { Tribhuvan } \\
\text { University }\end{array}$ & Department & Accredited \\
\hline 6 & $\begin{array}{l}\text { Central Department of Botany, } \\
\text { Kirtipur }\end{array}$ & $\begin{array}{l}\text { Tribhuvan } \\
\text { University }\end{array}$ & Department & Accredited \\
\hline 7 & $\begin{array}{l}\text { Central Department of } \\
\text { Biotechnology, Kirtipur }\end{array}$ & $\begin{array}{l}\text { Tribhuvan } \\
\text { University }\end{array}$ & Department & Accredited \\
\hline 8 & Balkumari College, Chitwan & $\begin{array}{l}\text { Tribhuvan } \\
\text { University }\end{array}$ & Community & Re-accredited \\
\hline 9 & Damak Multiple Campus, Jhapa & $\begin{array}{l}\text { Tribhuvan } \\
\text { University }\end{array}$ & Community & Re-accredited \\
\hline 10 & Lumbini Banijya Campus, Rupandehi & $\begin{array}{l}\text { Tribhuvan } \\
\text { University }\end{array}$ & Community & Re-accredited \\
\hline 11 & Kailali Multiple Campus, Kailali & $\begin{array}{l}\text { Tribhuvan } \\
\text { University }\end{array}$ & Community & Re-accredited \\
\hline 12 & $\begin{array}{l}\text { Makwanpur Multiple Campus, } \\
\text { Hetauda, Makwanpur }\end{array}$ & $\begin{array}{l}\text { Tribhuvan } \\
\text { University }\end{array}$ & Community & Re-accredited \\
\hline 13 & Janapriya Multiple Campus, Kaski & $\begin{array}{l}\text { Tribhuvan } \\
\text { University }\end{array}$ & Community & Re-accredited \\
\hline 14 & $\begin{array}{l}\text { Shaheed Smriti Multiple Campus, } \\
\text { Chitwan }\end{array}$ & $\begin{array}{l}\text { Tribhuvan } \\
\text { University }\end{array}$ & Community & Accredited \\
\hline 15 & $\begin{array}{l}\text { Aadikabi Bhanubhakta Campus, } \\
\text { Tanahun }\end{array}$ & $\begin{array}{l}\text { Tribhuvan } \\
\text { University }\end{array}$ & Community & Accredited \\
\hline 16 & Sukuna Multiple Campus, Morang & $\begin{array}{l}\text { Tribhuvan } \\
\text { University }\end{array}$ & Community & Accredited \\
\hline
\end{tabular}


Quality Assurance in Higher Education Institutions 12

\begin{tabular}{|c|c|c|c|c|}
\hline 17 & Sindhuli Multiple Campus, Sindhuli & $\begin{array}{l}\text { Tribhuvan } \\
\text { University }\end{array}$ & Community & Accredited \\
\hline 18 & $\begin{array}{l}\text { Madhyabindu Multiple Campus, } \\
\text { Nawalparasi }\end{array}$ & $\begin{array}{l}\text { Tribhuvan } \\
\text { University }\end{array}$ & Community & Accredited \\
\hline 19 & $\begin{array}{l}\text { Mahakavi Devkota Campus, } \\
\text { Nawalparasi }\end{array}$ & $\begin{array}{l}\text { Tribhuvan } \\
\text { University }\end{array}$ & Community & Accredited \\
\hline 20 & $\begin{array}{l}\text { Saptagandki Multiple Campus, } \\
\text { Chitwan }\end{array}$ & $\begin{array}{l}\text { Tribhuvan } \\
\text { University }\end{array}$ & Community & Accredited \\
\hline 21 & $\begin{array}{l}\text { Rupandehi Multiple Campus, } \\
\text { Rupandehi }\end{array}$ & $\begin{array}{l}\text { Tribhuvan } \\
\text { University }\end{array}$ & Community & Accredited \\
\hline 22 & $\begin{array}{l}\text { Dibya jyoti Multiple Campus, } \\
\text { Nawalparasi }\end{array}$ & $\begin{array}{l}\text { Tribhuvan } \\
\text { University }\end{array}$ & Community & Accredited \\
\hline 23 & Janta Multiple Campus, Sunsari & $\begin{array}{l}\text { Tribhuvan } \\
\text { University }\end{array}$ & Community & Accredited \\
\hline 24 & $\begin{array}{l}\text { Triyuga Janta Multiple Campus, } \\
\text { Udaypur }\end{array}$ & $\begin{array}{l}\text { Tribhuvan } \\
\text { University }\end{array}$ & Community & Accredited \\
\hline 25 & $\begin{array}{l}\text { Siddhartha Gautam Buddha Campus, } \\
\text { Rupandehi }\end{array}$ & $\begin{array}{l}\text { Tribhuvan } \\
\text { University }\end{array}$ & Community & Accredited \\
\hline 26 & Hari Khetan Multiple Campus & $\begin{array}{l}\text { Tribhuvan } \\
\text { University }\end{array}$ & Community & Accredited \\
\hline 27 & Resunga Multiple Campus & $\begin{array}{l}\text { Tribhuvan } \\
\text { University }\end{array}$ & Community & Accredited \\
\hline 28 & Rammani Multiple Campus & $\begin{array}{l}\text { Tribhuvan } \\
\text { University }\end{array}$ & Community & Accredited \\
\hline 29 & $\begin{array}{l}\text { J.S. Murarka Multiple Campus, } \\
\text { Siraha }\end{array}$ & $\begin{array}{l}\text { Tribhuvan } \\
\text { University }\end{array}$ & Community & Accredited \\
\hline 30 & Aishwarya Multiple Campus, Kailali & $\begin{array}{l}\text { Tribhuvan } \\
\text { University }\end{array}$ & Community & Accredited \\
\hline 31 & Kavre Multiple Campus & $\begin{array}{l}\text { Tribhuvan } \\
\text { University }\end{array}$ & Community & Accredited \\
\hline 32 & $\begin{array}{l}\text { Kanchan Bidhya Mandir Samudayik } \\
\text { College }\end{array}$ & $\begin{array}{l}\text { Tribhuvan } \\
\text { University }\end{array}$ & Community & Accredited \\
\hline 33 & Jana Bhawana Campus & $\begin{array}{l}\text { Tribhuvan } \\
\text { University }\end{array}$ & Community & Accredited \\
\hline 34 & Janamaitri Multiple Campus & $\begin{array}{l}\text { Tribhuvan } \\
\text { University }\end{array}$ & Community & Accredited \\
\hline 35 & Manthali Sahid smriti Multiple ampus & $\begin{array}{l}\text { Tribhuvan } \\
\text { University }\end{array}$ & Community & Accredited \\
\hline 36 & Myagdi Multiple Campus & $\begin{array}{l}\text { Tribhuvan } \\
\text { University }\end{array}$ & Community & Accredited \\
\hline 37 & Ghodaghodi Multiple Campus & $\begin{array}{l}\text { Tribhuvan } \\
\text { University }\end{array}$ & Community & Accredited \\
\hline 38 & $\begin{array}{l}\text { Sahid Narayan Pokharel Rampur } \\
\text { Campu, Rupendehi }\end{array}$ & $\begin{array}{l}\text { Tribhuvan } \\
\text { University }\end{array}$ & Community & Accredited \\
\hline 39 & Siddhartha Campus, Kapilvastu & $\begin{array}{l}\text { Tribhuvan } \\
\text { University }\end{array}$ & Community & Accredited \\
\hline 40 & Nilkantha Multiple Campus, Dhading & $\begin{array}{l}\text { Tribhuvan } \\
\text { University }\end{array}$ & Community & Accredited \\
\hline 41 & Kathmandu BernHardt College & $\begin{array}{l}\text { Tribhuvan } \\
\text { University }\end{array}$ & Private & Accredited \\
\hline 42 & $\begin{array}{l}\text { Kathmandu University, School of } \\
\text { Science }\end{array}$ & $\begin{array}{l}\text { Kathmandu } \\
\text { University }\end{array}$ & School & Re-accredited \\
\hline 43 & $\begin{array}{l}\text { Kathmandu University, School of } \\
\text { Engineering }\end{array}$ & $\begin{array}{l}\text { Kathmandu } \\
\text { University }\end{array}$ & School & Accredited \\
\hline
\end{tabular}


Quality Assurance in Higher Education Institutions 13

\begin{tabular}{|l|l|l|l|l|}
\hline 44 & School of Education, KU & $\begin{array}{l}\text { Kathmandu } \\
\text { University }\end{array}$ & School & Accredited \\
\hline 45 & School of Arts, KU & $\begin{array}{l}\text { Kathmandu } \\
\text { University }\end{array}$ & School & Accredited \\
\hline 46 & $\begin{array}{l}\text { Siddhanath Multiple Campus, } \\
\text { Kanchanpur }\end{array}$ & $\begin{array}{l}\text { Far-Western } \\
\text { University }\end{array}$ & Community & Accredited \\
\hline 47 & Tikapur Multiple Campus, Kailali & $\begin{array}{l}\text { Far-Western } \\
\text { University }\end{array}$ & Constituent & Re-accredited \\
\hline 49 & $\begin{array}{l}\text { College of Biomedical Engineering } \\
\text { and Applied Business, Kathmandu }\end{array}$ & $\begin{array}{l}\text { Purbanchal } \\
\text { University }\end{array}$ & Private & Accredited \\
\hline $\begin{array}{l}\text { Tribhuvan University }=41 \\
\text { Kathmandu University }=4 \\
\text { Far-Western University }=2 \\
\text { Purbanchal University }=1 \\
\text { Foreign Affiliation Salzburg University = } 1 \\
\text { Grand Total Accredited HEIs in Nepal = 49 }\end{array}$ & $\begin{array}{l}\text { Foreign Affiliation } \\
\text { Salzburg University }\end{array}$ & Private & Accredited \\
\hline
\end{tabular}

Source: Chaulagai, Nabina. "Current Status of Accredited Higher Education Institutions in Nepal (2007- 2020).” Received by Min Pun, 28 June 2020. Email Interview. 